(c) 2021 by «D. Rogachev NMRCPHOI»

Received 27.06.2021 Accepted 15.07.2021

Correspondence: Aliaa Mohammed Diab, Pediatric Department, Faculty of Medicine, Benha University E-mail: aliaadiabdyahoo.com

\title{
Prognostic evaluation of immune thrombocytopenia outcomes in Egyptian children: a retrospective single-center experience
}

Aliaa Mohammed Diab ${ }^{1}$, AlRawhaa Ahmed Abouamer ${ }^{1}$, Ghada Saad Abdel Motaleb ${ }^{1}$ Khaled Abdelaziem Eid², Heba Ismaiel Abdelnaiem ${ }^{1}$

${ }^{1}$ Benha University, Benha, Egypt

${ }^{2}$ Cairo University, Cairo, Egypt

Immune thrombocytopenia (ITP) is the most common cause of thrombocytopenia in children. This retrospective study was designed to analyze presenting features of ITP cases in Benha, evaluate outcomes in children and determine prognostic factors. This research was accepted by Research Ethics Committee (REC) of Faculty of Medicine, Benha University (chairman: Prof. Nermeen Adly Mahmoud). Ethics comittee refrence number MS 40-3/2019. Records of 308 children with ITP in Benha University Hospitals and Benha Children Hospital haematology clinics between May 2014 and January 2021 were retrospectively analyzed. Socio-demographic, clinical, and laboratory data of the studied children such as age, gender, the type of residence, the date of diagnosis, complaints at presentation, preceding vaccination or infection, the type of bleeding, initial platelet count, LDH (lactate dehydrogenase) level, initial treatment, and outcomes were recorded. A total of 308 children diagnosed with ITP were included, clinical courses were determined as newly diagnosed and chronic in $71.4 \%$ and $28.6 \%$, respectively. The median age of patients at diagnosis was $5 \pm 3.4$ years. The male/female ratio was 1.14. The median age at diagnosis was significantly higher in chronic ITP patients $(p<0.001)$; patients $\geq 10$ years were more likely to develop chronic ITP than younger ones $(p=0.029)$. Regarding residency, seasonality, type of bleeding and history of preceding infection or vaccination, the difference was not statistically significant. Initial platelet counts $>20 \times 10^{9}$ were significantly more prevalent in chronic ITP $(p<0.001)$. LDH level at presentation was significantly higher in chronic cases $(p=0.046)$. Initial lines of treatment were the following: steroids, IVIG, and IVIG with steroids (in $88 \%$, $5.2 \%$, and $2.9 \%$ of the cases, respectively). A total of $3.9 \%$ of the children did not receive any treatment. There was no significant difference in the outcomes between the initial lines of treatment $(p=0.105)$. In our study, age > 10 years, female gender, higher platelet count and high LDH level at presentation were found to increase the probability of chronic ITP.

Key words: primary immune thrombocytopenia, immune thrombocytopenia outcome, immune thrombocytopenia prognostic factors

Diab A.M., et al. Pediatric Hematology/Oncology and Immunopathology. 2021; 20 (3): 26-30. DOl: $10.24287 / 1726-1708-2021-20-3-26-30$

\footnotetext{
$\mathrm{P}$
} rimary immune thrombocytopenia (ITP) is an autoimmune disorder characterized by platelet count less than $100 \times 10^{\%} / \mathrm{L}$ in the absence of other causes. The disease is caused by increased platelet destruction by humoral or cellular immune mechanisms and often by inappropriate platelet production in the bone marrow [1]. The exact incidence is unknown, but it is estimated that $1 / 10,000$ children each year is affected [2]. About 3 out of 4 children will recover from ITP within 12 months from their diagnosis [3]. The diagnosis of ITP is established when there is no clinically apparent associated conditions that may cause thrombocytopenia after a thorough history and physical examination. Findings that suggest a diagnosis other than ITP include the enlargement of lymph nodes, liver, spleen, or systemic symptoms (e.g., fever, anorexia, bone or joint pain, or weight loss) [4]. Children who have no or mild bleeding can be managed with observation alone, regardless of platelet count. In cases requiring treatment, intravenous immunoglobulin (IVIG), anti-D immunoglobulin, or corticosteroids can be administered [5]. When, despite repeated doses of first-line treatment, the disease becomes resistant and chronic, lasting more than twelve months, other treatments should be applied. The use of the thrombopoietin receptor agonist eltrombopag has been approved in children older than one year with chronic ITP who have not responded to the first-line drugs [6]. In refractory cases, other options are the use of rituximab or less specific immunosuppressant drugs (e.g., cyclosporine, azathioprine, and mycophenolate mofetil) [7].

Aim of the study. To analyze the details of ITP cases, evaluate the outcomes among children in Benha and determine the prognostic factors as guidelines for new cases at the time of diagnosis. 


\section{MATERIALS AND METHODS}

\section{Study subjects}

This retrospective study was conducted in $\mathrm{Al}-\mathrm{Qa}-$ lubyia Governorate at Haematology Clinics in Benha University Hospitals and Benha Children Hospital.

The data of patients with ITP (aged between 6 months and 17 years) admitted to Behna hospitals from May 2014 to January 2021 were collected.

Inclusion criteria:

- Patients diagnosed with ITP

- Age: from 6 months to $\leq 18$ years

Exclusion criteria:

- Patients with significant lymphadenopathy, hepatomegaly, splenomegaly or systemic symptoms (e.g., bone or joint pain, or weight loss etc.) and atypical bone marrow findings.

- Cases diagnosed with ITP and associated with another chronic disease (e.g., chronic renal failure, chronic liver disease).

- Patients with other autoimmune diseases, such as hypothyroidism, celiac disease, etc.).

\section{Methods}

Three hundred and eight children diagnosed with ITP and followed up in pediatric haematology clinics in Benha University Hospitals and Benha Children Hospital were included.

A specially designed sheet was used to collect socio-demographic, clinical, and laboratory data of the studied children. Such information as age, gender, residence, date of diagnosis, complaints at presentation, as well as data on previous infection or vaccination, type of bleeding, initial platelet count, LDH level, initial treatment and follow-up of the disease were recorded.

\section{Ethical consideration}

This research was accepted by Research Ethics Committee (REC) of Faculty of Medicine, Benha University (chairman: Prof. Nermeen Adly Mahmoud). Ethics comittee refrence number MS 40-3/2019.

\section{Statistical analysis}

The collected data were tabulated and analyzed using SPSS version 16 software (SpssInc, Chicago, ILL Company). Categorical data were presented as numbers and percentages, Chi squared $\left(\chi^{2}\right)$ test and Fisher's exact test were used to analyze them. Quantitative data were tested for normality using Kolmogorov-Smirnov test, assuming normality at $p>0.05$. Normally distributed variables were expressed as mean \pm standard deviation, while nonparametric data were presented as median, $I Q R$, and range and analyzed by Mann-Whitney $U$ test. $P \leq 0.05$ was considered significant.

\section{RESULTS}

Out of 308 patients, 164 (53.2\%) were males, and $144(46.8 \%)$ were females; the median age of patients at diagnosis was $5 \pm 3.4$ years, the majority of the children were in the age group from 2 to 10 years old $(72.7 \%)$. The incidence was higher in rural areas $(61.7 \%)$ than in urban areas. The incidence in summer was higher $(39.6 \%)$ than in other seasons of the year. Our study showed that about $90.9 \%$ of the study group had no history of preceding vaccination, and about $17.5 \%$ of the patients had a previous infection $(14.9 \%$ and $2.6 \%$ of the patients had a history of upper respiratory tract infection and acute gastroenteritis, respectively). A total of $4.2 \%$ of the patients had positive consanguinity and $3.9 \%$ of the children had a positive family history for ITP (table 1).

Table 1

Baseline characteristics of the children diagnosed with ITP

\begin{tabular}{|c|c|c|c|}
\hline Variable & & $\begin{array}{l}\text { Number of the patients } \\
\qquad(n=308)\end{array}$ & $\%$ \\
\hline \multirow[t]{3}{*}{ Age (years) } & Median \pm SD & \multicolumn{2}{|l|}{$5.0 \pm 3.4$} \\
\hline & Range & \multicolumn{2}{|l|}{$0.5-17$} \\
\hline & $\begin{array}{c}<2 \text { years } \\
2-10 \text { years } \\
>10 \text { years }\end{array}$ & $\begin{array}{c}40 \\
220 \\
48\end{array}$ & $\begin{array}{l}13.0 \\
71.4 \\
15.6 \\
\end{array}$ \\
\hline \multirow[t]{2}{*}{ Gender } & Male & 164 & 53.2 \\
\hline & Female & 144 & 46.8 \\
\hline \multirow[t]{2}{*}{ Residence } & Urban & 118 & 38.3 \\
\hline & Rural & 190 & 61.7 \\
\hline \multirow[t]{4}{*}{ Season } & Winter & 70 & 22.7 \\
\hline & Spring & 78 & 25.3 \\
\hline & Summer & 122 & 39.6 \\
\hline & Autumn & 38 & 12.4 \\
\hline $\begin{array}{l}\text { Preceding } \\
\text { infection }\end{array}$ & $\begin{array}{l}\text { URTI } \\
\text { GE } \\
\text { No }\end{array}$ & $\begin{array}{c}46 \\
8 \\
254\end{array}$ & $\begin{array}{c}14.9 \\
2.6 \\
82.5\end{array}$ \\
\hline $\begin{array}{l}\text { Preceding } \\
\text { vaccination }\end{array}$ & $\begin{array}{l}\text { Yes } \\
\text { No }\end{array}$ & $\begin{array}{c}28 \\
280 \\
\end{array}$ & $\begin{array}{r}9.1 \\
90.9 \\
\end{array}$ \\
\hline Family history & $\begin{array}{l}\text { Positive } \\
\text { Negative }\end{array}$ & $\begin{array}{c}12 \\
296\end{array}$ & $\begin{array}{l}3.9 \\
96.1\end{array}$ \\
\hline Consanguinity & $\begin{array}{l}\text { Positive } \\
\text { Negative }\end{array}$ & $\begin{array}{c}13 \\
395\end{array}$ & $\begin{array}{l}4.2 \\
95.8\end{array}$ \\
\hline
\end{tabular}

Also, about $97 \%$ of the study group had cutaneous manifestations, $18.5 \%$ of them had mucosal bleeding, and only $8(2.6 \%)$ cases presented with other complaints, such as pallor, fatigue, and blurring of vision.

Our study showed that $220(71.4 \%)$ cases had acute ITP, and $88(23.6 \%)$ patients had chronic ITP. Older age was an important predictor of chronic disease with the median age of $8 \pm 3.1$ years in comparison to the median age of $3.8 \pm 3.0$ years in acute cases $(p<0.001)$. Patients aged $\geq 10$ years developed chronic disease more often than younger ones $(p=0.029)$. Regarding gender distribution, our study showed that 
females (58\%) were more likely to develop chronic ITP than males $(42 \%)(p=0.013)$. According to the present study, the type of bleeding, the residency of patients, the season when a patient developed ITP, consanguinity and family history did not significantly modify the course of the disease (table 2). Also, the history of previous infection and preceding vaccination did not significantly affect the disease course.

Table 2

Demographic data outcome in ITP cases

\begin{tabular}{|c|c|c|c|c|}
\hline Variable & & $\begin{array}{l}\text { Acute ITP } \\
(n=220)\end{array}$ & $\begin{array}{c}\text { Chronic ITP } \\
(n=88)\end{array}$ & $p$ value \\
\hline \multirow[t]{2}{*}{ Age (years) } & $\begin{array}{c}\text { Median } \pm \text { SD } \\
\text { Range } \\
<2 \text { years, } \\
n(\%) \\
2-10 \text { years, } \\
n(\%) \\
>10 \text { years, } \\
n(\%)\end{array}$ & $\begin{array}{c}3.8+3.0 \\
0.5-17 \\
34(15.5) \\
158(71.8) \\
28(12.7)\end{array}$ & $\begin{array}{c}8.0+3.1 \\
1.5-15 \\
6(6.8) \\
62(70.5) \\
20(22.7)\end{array}$ & $<0.001^{\dagger}$ \\
\hline & $\begin{array}{l}<10 \text { years } \\
>10 \text { years }\end{array}$ & $\begin{array}{c}192(87.3) \\
28(12.7)\end{array}$ & $\begin{array}{l}68(77.3) \\
20(22.7)\end{array}$ & 0.022 \\
\hline Gender & $\begin{array}{c}\text { Male } \\
\text { Female }\end{array}$ & $\begin{array}{l}127(57.7) \\
93(42.3)\end{array}$ & $\begin{array}{l}37(42.0) \\
51(58.0)\end{array}$ & 0.013 \\
\hline Residence & $\begin{array}{l}\text { Urban } \\
\text { Rural }\end{array}$ & $\begin{array}{c}86(39.1) \\
134(60.9)\end{array}$ & $\begin{array}{l}32(36.4) \\
56(63.6)\end{array}$ & 0.656 \\
\hline Season & $\begin{array}{l}\text { Winter } \\
\text { Spring } \\
\text { Summer } \\
\text { Autumn }\end{array}$ & $\begin{array}{l}50(22.7) \\
60(27.3) \\
88(40.0) \\
22(10.0)\end{array}$ & $\begin{array}{l}20(22.7) \\
18(20.5) \\
34(38.6) \\
16(18.2)\end{array}$ & 0.204 \\
\hline $\begin{array}{l}\text { Preceding } \\
\text { infection }\end{array}$ & $\begin{array}{l}\text { URTI } \\
\text { GE } \\
\text { No }\end{array}$ & $\begin{array}{c}36(16.4) \\
6(2.7) \\
178(80.9)\end{array}$ & $\begin{array}{c}10(11.4) \\
2(2.3) \\
76(86.4)\end{array}$ & $0.516^{*}$ \\
\hline $\begin{array}{l}\text { Preceding } \\
\text { vaccination }\end{array}$ & $\begin{array}{l}\text { Yes } \\
\text { No }\end{array}$ & $\begin{array}{c}18(8.2) \\
202(91.8)\end{array}$ & $\begin{array}{l}10(11.4) \\
78(88.6)\end{array}$ & 0.38 \\
\hline Family history & $\begin{array}{l}\text { Positive } \\
\text { Negative }\end{array}$ & $\begin{array}{c}6(2.7) \\
214(97.3)\end{array}$ & $\begin{array}{c}6(6.8) \\
82(93.2)\end{array}$ & $0.108^{*}$ \\
\hline Consanguinity & $\begin{array}{l}\text { Positive } \\
\text { Negative }\end{array}$ & $\begin{array}{c}7(3.2) \\
213(96.8)\end{array}$ & $\begin{array}{c}6(6.8) \\
82(93.2)\end{array}$ & $0.206^{*}$ \\
\hline
\end{tabular}

We found that $3.2 \%$ of the patients had no medication, $96.7 \%$ received steroid therapy, while $0.6 \%$ received IVIG therapy and $20 \%$ received combined therapy. Initial treatment was steroids or no treatment and statistically, there was no significant difference in the outcome ( $p=0.119)$.

According to the present study, at the time of diagnosis, steroids were administered to $88 \%$ of the patients, IVIG to $5.2 \%$ of the patients and IVIG with steroids to $2.9 \%$ of the patients, while $3.9 \%$ of the patients did not receive any treatment (observation only group). Statistically there was no significant difference in the outcomes between initial lines of treatment $(p=0.105)$ (table 3).

Table 3

Initial lines of treatment in ITP cases

\begin{tabular}{|c|c|c|c|}
\hline \multirow{2}{*}{ Initial treatment } & $\begin{array}{l}\text { Acute ITP } \\
(n=220)\end{array}$ & $\begin{array}{c}\text { Chronic ITP } \\
(n=88)\end{array}$ & $p$ value \\
\hline & $n(\%)$ & $n(\%)$ & \multirow{5}{*}{0.105} \\
\hline Steroids & $190(86.4)$ & 81 (92.0) & \\
\hline IVIG & $12(5.5)$ & $4(4.5)$ & \\
\hline IVIG + steroids & $6(2.7)$ & $3(3.4)$ & \\
\hline Observation & $12(5.5)$ & $0(0.0)$ & \\
\hline
\end{tabular}

Our study showed a significant difference in initial platelet counts between acute and chronic ITP, the median platelet count was $13 \times 10^{9}$ (range 2-54) in acute cases. We found that the median platelet count at diagnosis and platelet count $>20 \times 10^{9}$ was significantly higher in patients who developed chronic ITP (the median platelet count was $18.5 \times 10^{9}$ (range 3-60) $(p<0.001)$ ) (figure 1$)$. Our study showed that LDH is an important predictor of chronic ITP (figure 2) as the median LDH level was significantly higher in chronic cases (746 U/L) compared to acute cases; the median was $714 \mathrm{U} / \mathrm{L}(p=0.002)$ (table 4$)$.

Figure 1

Box plot showing initial platelet counts (median and IQR)

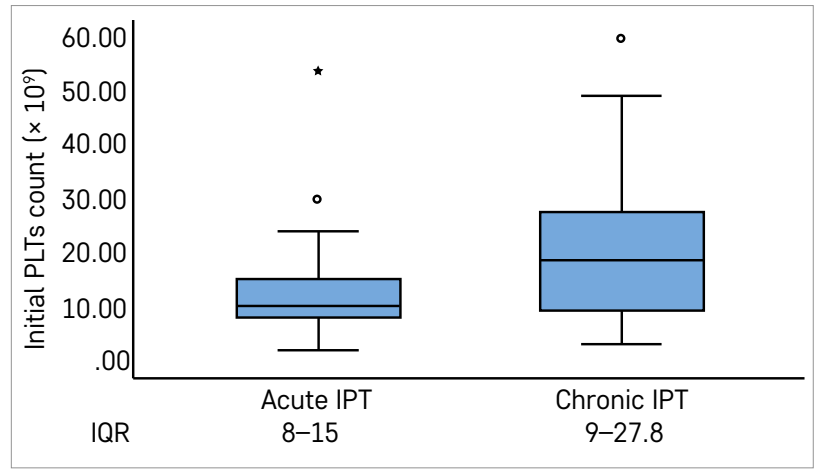

Figure 2

Box plot showing LDH at presentation (median and IQR)

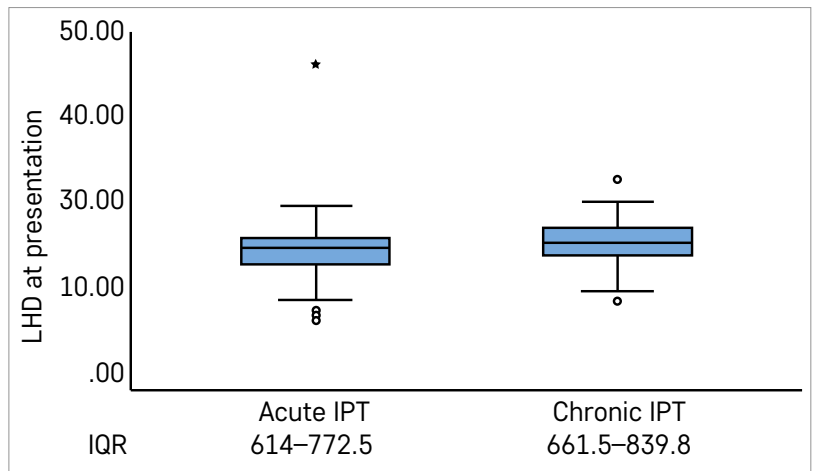

Table 4

Initial PLT and LDH and outcomes of ITP patients

\begin{tabular}{|c|c|c|c|c|c|}
\hline & \multicolumn{2}{|c|}{ Acute ITP } & \multicolumn{2}{|c|}{ Chronic ITP } & \multirow{2}{*}{$p$ value } \\
\hline & median & range & median & range & \\
\hline $\begin{array}{l}\mathrm{LDH} \text { at } \\
\text { presentation }\end{array}$ & 714 & $286-1800$ & 746 & $402-1122$ & 0.002 \\
\hline $\begin{array}{l}\text { Initial platelet } \\
\text { count, } \times 10^{9}\end{array}$ & 10 & $2-54$ & 18.5 & $3-60$ & $<0.001$ \\
\hline $\begin{array}{l}<20 \times 10^{9} \\
>20 \times 10^{9}\end{array}$ & $\begin{array}{c}n \\
194 \\
26\end{array}$ & $\begin{array}{c}\% \% \\
88.2 \\
11.8\end{array}$ & $\begin{array}{c}n \\
50 \\
38\end{array}$ & $\begin{array}{c}\% \\
56.8 \\
43.2\end{array}$ & $<0.001$ \\
\hline
\end{tabular}

\section{DISCUSSION}

Our retrospective study was designed to determine the presenting features and the clinical characteristics of diagnosed immune thrombocytopenia cases (ITP) among studied children. It also aims to determine 
the prognostic factors that could predict the disease course at diagnosis. The ages of the studied cases in the present study ranged between 6 months to 17 years, with a median age of 5 years. Makis et al. [8] similarly showed that the median age of incidence was 4.8 years in their retrospective study. Also, Yong et al. [9] agreed with this.

Our study showed a higher incidence in males than females (1.14:1) with no significance. This agrees with Saeidi et al. [10] and Nazari et al. [11] as they found a higher incidence in males.

Our results showed a higher incidence in rural areas compared to urban areas. Contrary to this result, AL-Zuhairy [12] found that about two-thirds of the patients diagnosed with ITP lived in Iraq's urban areas. Our study showed a higher incidence in summer than in other seasons of the year. This disagrees with Yong et al. [9] as they found a higher incidence in winter than other seasons of the year.

Our study showed that about $9.1 \%$ of the patients had a history of preceding vaccination before diagnosis. This agreed with Yong et al. [9] who found that 8.6\% of patients received vaccination shortly before the ITP diagnosis, and France et al. [13] who found that 3.2\% of patients received MMR vaccine before the ITP diagnosis.

Our study showed that $17.5 \%$ of the patients had a history of previous infection: $85.2 \%$ of them had a history of upper respiratory tract infection, and $14.8 \%$ of them had a history of gastroenteritis. This agrees with Söğüt et al. [14] who found that $22.5 \%$ of patients had evidence of infection before ITP diagnosis: $85 \%$ of them had a history of upper respiratory tract infection, and $15 \%$ of them had a history of acute gastroenteritis (AGE). However, the number of patients with a history of previous infection in our study was less than in Makis et al. [8] study, where $65 \%$ of newly diagnosed patients had a previous infection.

Our study showed that most of the study group (97.1\%) had cutaneous bleeding such as petechiae, ecchymosis or both, and $18.5 \%$ had mucosal bleeding. This agrees with AL-Zuhairy [12] who showed that petechiae and/or bruising were the most common (92\%) clinical features among children diagnosed with ITP, but in Makis et al. [8] study, the number of patients with mucosal bleeding was less $(70 \%)$. Our study showed that at the time of presentation, the patients had elevated LDH levels (242 of our cases had data on LDH levels available). This agrees with Al-Samkari and Kuter [15] who found a statistically significant inverse correlation between LDH level and platelet count, as LDH is present in numerous cell types including platelets.

In this study, $71.4 \%$ and $28.6 \%$ of the cases had acute and chronic ITP, respectively. Grimaldi-Bensouda et al. [16] also found that $24.2 \%$ of cases developed chronic ITP and Singh et al. [17] found that chronic ITP represents $15-20 \%$ of cases.

In the present study, there was a significant correlation between the age of the patients and the course of the disease. We found that the median age of chronic cases was 8 years and children aged $\geq 10$ years had a significantly higher incidence of chronic ITP. This agrees with Gungor et al. [18] who found that age $\geq 10$ years is a predictor of chronic ITP. This also agrees with Donato et al. [19] and Watts et al. [20] who revealed that older age was an important predictor of chronic disease.

There was no statistically significant difference between initial treatment and the course of the disease which is consistent with Bansal et al. [21]. Regarding gender distribution, our study revealed that females had a higher incidence to be chronic than males. This is consistent with Nazari et al. [11] who found that the female gender is an indicator for chronicity; this may be explained by the fact that, as in other immune disorders, sex hormones may play a role in the susceptibility to chronicity. In addition to impacting the immune system, sex hormones may also alter the clinical picture and response to therapy. In the present study, the residency of patients did not significantly modify the course of the disease. Also, there was no significant correlation between the season in which patients showed their first symptoms and the disease's course; this is supported by Akbayram et al. [22]. Also, the type of bleeding did not significantly modify the disease's course; this result was supported by Akbayram et al. [22].

Our study showed that there is a significant difference in initial platelet counts between the patients with acute ITP and chronic ITP as the median platelet count was $10 \times 10^{\circ} / \mathrm{L}$ in acute cases and $18.5 \times 10^{9} / \mathrm{L}$ in chronic cases, so we found a significantly higher median platelet count at diagnosis in patients who developed chronic ITP. This result agrees with Makis et al. [8] as the median platelet count at diagnosis was $14.6 \times 10^{9} / \mathrm{L}$ in acute ITP and $26.3 \times 10^{9} / \mathrm{L}$ in chronic cases. Also, our study showed that in chronic cases, the patients had a significantly higher platelet count $\left(\geq 20 \times 10^{9} / L\right)$ than in acute cases; this is consistent with Gungor et al. [18].

Our study showed that LDH was an important predictor of chronic ITP; it was elevated in all ITP cases but was higher in cases of chronic ITP with the median level of $752 \mathrm{U} / \mathrm{L}$ vs $686 \mathrm{U} / \mathrm{L}$ in acute cases.

\section{CONCLUSIONS}

- Age $\geq 10$ years is an important predictor of chronic disease. 
- Females are more likely to develop chronic ITP than males.

- There is a statistically significant difference in initial platelet counts between patients with different courses of the disease.

- High LDH level is an important predictor of chronic ITP.
FUNDING

Not specified.

\section{CONFLICT OF INTEREST}

The authors declare that there is no conflict of interest.

\section{References}

1. Abadi U., Yarchovsky-Dolberg 0., Ellis M.H. Immune thrombocytopenia: recent progress in pathophysiology and treatment. Clin Appl Thromb Hemost 2015;21 (5): 397-404.

2. Lanzkowsky P., ed. Manual of pediatric hematology and oncology. Elsevier; 2005 Jun. 4th ed; chapter 10, p: 250-9.

3. Imbach P., Kühne T., Müller D., Berchtold W., Zimmerman S., Elalfy M., et al. Childhood ITP: 12 months follow-up data from the prospective registry I of the Intercontinental Childhood ITP Study Group (ICIS). Pediatr Blood Cancer 2006; 46 (3): 351-6.

4. Rodeghiero F., Stasi R., Gernsheimer T., Michel M., Provan D., Arnold D.M., et al. Standardization of terminology, definitions and outcome criteria in immune thrombocytopenic purpura of adults and children: report from an international working group. Blood 2009; 113 (11): 2386-93.

5. Provan D., Stasi R., Newland A.C., Blanchette V.S., Bolton-Maggs P., Bussel J.B., et al. International consensus report on the investigation and management of primary immune thrombocytopenia. Blood 2010; 115 (2): 168-86.

6. Burness C.B., Keating G.M., Garnock-Jones K.P. Eltrombopag: a review in paediatric chronic immune thrombocytopenia. Drugs 2016; 76 (8): 869-78.

7. Liang Y., Zhang L., Gao J., Hu D., Ai Y. Rituximab for children with immune thrombocytopenia: a systematic review. PloS One 2012; 7 (5): e36698.

8. Makis A., Gkoutsias A., Palianopoulos T., Pappa E., Papapetrou E., Tsaousi C., et al. Prognostic factors for immune thrombocytopenia out- come in Greek children: A retrospective single-centered analysis. Adv Hematol 2017; 2017: 7878605.

9. Yong M., Schoonen W.M., Li L., Kanas G., Coalson J., Mowat F., et al. Epidemiology of paediatric immune thrombocytopenia in the General Practice Research Database. $\mathrm{Br} \mathrm{J}$ Haematol 2010; 149 (6): 855-64.

10. Saeidi S., Jaseb K., Asnafi A.A., Rahim F., Pourmotahari F., Mardaniyan S., et al. Immune thrombocytopenic purpura in children and adults: a comparative retrospective study in IRAN. Int J Hematol Oncology Stem Cell Res 2014; 8 (3): 30.

11. Nazari S.H., Abdollah G.F., Sadeghi K.M. Epidemiology of idiopathic thrombocytopenic purpura in children. Iran J Pediatric Hematol Oncol 2012; 2 (1): 35-9.

12. AL-Zuhairy S.H. Evaluation of prognostic factors in newly diagnosed childhood primary immune thrombocytopenia (ITP): two-year prospective study at Al-Sadder Hospital, Missan Province. Med J Babylon 2013; 10: 855-69.

13. France E.K., Glanz J., Xu S., Hambidge S., Yamasaki K., Black S.B., et al. Risk of immune thrombocytopenic purpura after measles-mumps-rubella immunization in children. Pediatrics 2008; 121 (3): e687-92.

14. Söğüt G., Leblebisatan G., Barutçu A., Kilinç Y., Şaşmaz H.I. Evaluation of Pediatric Patients with Immune Thrombocytopenia Regarding Clinical Course and Treatment Response: A Retrospective Single-Center Experience. Pediatr Pract Res 2020; 8 (2): 38-42.

15. Al-Samkari H., Kuter D.J. Lactate dehydrogenase is elevated in immune thrombocytopenia and inversely cor- relates with platelet count. $\mathrm{Br} \mathrm{J}$ Haematol 2019; 187 (3): e61-4.

16. Grimaldi-Bensouda L., Nordon C., Leblanc T., Abenhaim L., Allali S., Armari-Alla C., et al. Childhood immune thrombocytopenia: A nationwide cohort study on condition management and outcomes. Pediatr Blood Cancer 2017; 64 (7): e26389.

17. Singh G., Bansal D., Wright N.A. Immune thrombocytopenia in children: Consensus and controversies. Ind J Pediatr 2020; 87 (2): 150-7.

18. Güngör T., Bilir Ö.A., Çulha V.K., Güngör A., Kara A., Azık F.M., et al. Retrospective evaluation of children with immune thrombocytopenic purpura and factors contributing to chronicity. Pediatr Neonatol 2019; 60 (4): 411-6.

19. Donato H., Picón A., Martinez M., Rapetti M.C., Rosso A., Gomez S., et al. Demographic data, natural history, and prognostic factors of idiopathic thrombocytopenic purpura in children: a multicentered study from Argentina. Pediatr Blood Cancer 2009; 52 (4): 491-6.

20. Watts R.G. Idiopathic thrombocytopenic purpura: a 10 -year natural history study at the childrens hospital of alabama. Clini Pediatr 2004; 43 (8): 691-702.

21. Bansal D., Bhamare T.A., Trehan A., Ahluwalia J., Varma N., Marwaha R.K. Outcome of chronic idiopathic thrombocytopenic purpura in children. Pediatr Blood Cancer 2010; 54 (3): 403-7.

22. Akbayram S., Dogan M., Ustyol L., Akgun C., Peker E., Bilici S., et al. The clinical outcome of 260 pediatric ITP patients in one center. Clin Appl Thromb Hemost 2011; 17 (6): e30-5. 